\section{ANCIENT BRITISH LONG BARROWS}

THERE are many hopeful signs that the number of persons to whom all knowledge of nature is dear for its own sake is steadily on the increase; but it is, unfortunately, true that science still requires some adventitious aid to secure the attention of the general public. We must, therefore, look upon it as a matter of congratulation that even the Irish Question has been found to have a scientific aspect, and has recently awakened some general interest in so obscure a subject as that of the ethnology of England and Ireland.

It is not our present intention to enter upon the longstanding controversy as to the physical characters of the so-called Kelts, as we think that the materials for a satisfactory solution of the various questions involved are still very insufficient, notwithstanding the large amount of really riflers of grave-mounds and endless discussion of the scraps of information handed down by Greek and Roman anthors; but of thorough and extended investigation of pre-historic monuments of any one class or of any given district, with a view to elucidating the ethrography and early history of the country rather than with the object of collecting specimens for the museum, we have all too little to show.

The late Mr. Bateman devoted considerable attention to the pre-historic archæology of Derbyshire and the adjoining counties, but his extensive investigations do not appear to have been conducted with the care or described with the accuracy necessary for scientific purposes. The important researches for remains of our early ancestors, made by Sir Richard Hoare and Mr. Cunnington in the richest district in all England, were undertaken so long ago as the beginning of the century; and although

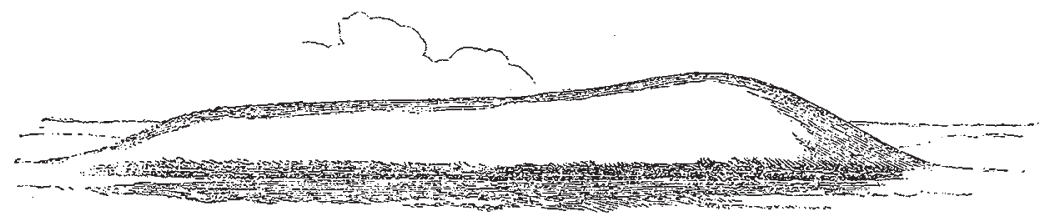

Fig. I, -A Long Barkow (after Sir Rd. Hoare)

trusiworthy evidence collected of late years by Broca, the explorations are recorded in full detail in Sir Richard's Pruner Bey, and others in France, and by Barnard Davis, great work," Ancient Wiltshire," the general results have not Thurnam, Beddoe, and Wilson in our own country. Few hitherto been fully and satisfactorily worked out. This want persons have any idea of the time, skill, and patience has, however, at length been supplied in a memoir* recently necessary for any satisfactory investigation either of the communicated to the Society of Antiquaries by Dr. John ethnic composition of existing populations, or of the Thurnam, a gentleman who possesses the rarely com-

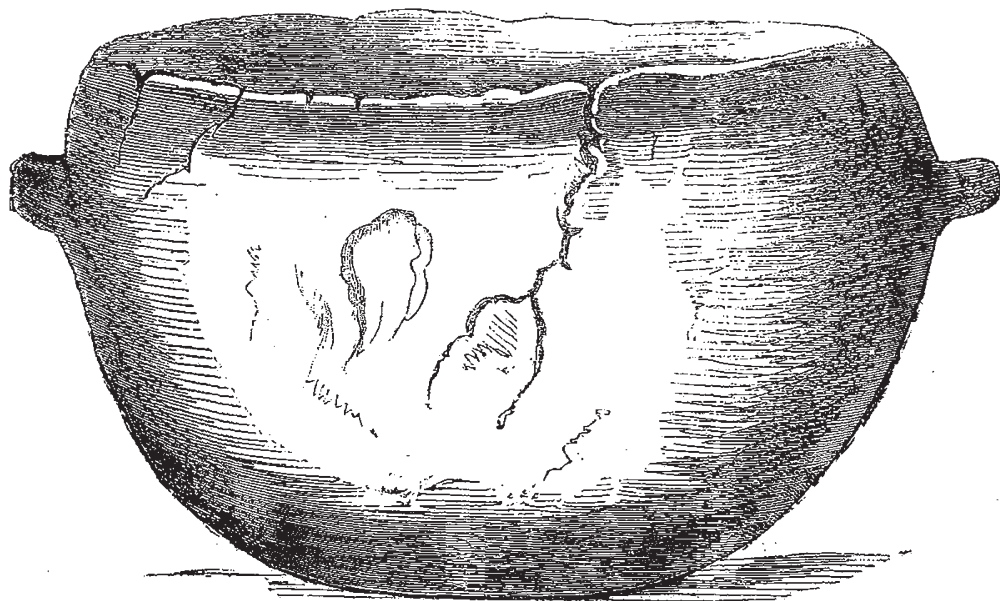

Fig. 2,-Vessel with Primary Interment. Norton Bavant, Long Barrow (scale z linear)

characters and affinities of the earlier races whose works and remains have come down to us. It may seem surprising that we should be long in doubt on matters apparently so easily settled as the average stature, prevailing head-form, and distribution of colour of hair and eyes, in various districts of our own and neighbouring countries; but it must be remembered that the number of persons interested in this branch of inquiry is extremely small, and that the collection of anthropological statistics by inaccurate or improperly instructed observers is very much to be deprecated. If the scientific study of existing populations is surrounded with difficulties and can reckon but few votaries, still more is this the case with the investigation of the character and affinities of the races inhabiting Western Europe at the dawn of history and in pre-historic times. We have had innumerable bined qualifications of classical scholarship, antiquarian knowledge, and familiarity with scientific method, and who is well known as one of the authors of the "Crania Britannica," undoubtedly the most valuable contribution to the ethnology of this country which has yet been published. The memoir in question is not a mere analysis of the labours of the Wiltshire baronet and his coadjutor; it is to a large extent a record of original explorations, more especially of a class of monuments somewhat neglected by Sir Richard Hoare, but to which the greatest interest attaches now that the advances in certain departments of anatomical knowledge enable us to turn to due account the evidence afforded by human remains.

* On ancient British Barrows, especially those of Wiltshire and the adjoining counties. Part I. Long Barrows. From the "Archaologia," vol. xlii.
r869. 
The monuments to which we refer are the huge gravemounds known as Long Barrows, and chiefly occurring in Wiltshire and the adjoining counties.

Only the first part of Dr. Thurnam's memoir has as yet been published-that, namely, relating specially to the Long Barrows; but this part is of sufficient importance to demand separate notice at our hands.

The chief result of the examination of the Ancient British barrows of the south-west of England is their division into two great classes-(I) the Long Barrows, the primary interments of which have yielded implements of stone and bone only, and which are, therefore, contidently assigned to the Stone Age ; and (2) the Round Barrows, affording implements of bronze as well as of stone, and occasionally, though rarely, of iron. The round barrows vary considerably in form, and Dr. Thumam thinks that these variations are not to be attributed to the individual
The immense size of the mounds of the South Wilts and Dorsetshire long barrows, and the imposing stone structures of those of North Wilts, Gloucestershire, and Somersetshire, would alone be sufficient, notwithstanding the rude character of the implements contained in them, to lead one to conclude that we have here the graves of the chieftains of the primitive people of these districts. The situations chosen for the grave-mounds, and the evidence, hereafter to be alluded to, of the immolation of slaves, and perhaps wives and children, seem strongly to confirm this supposition.

It will be convenient in the remainder of our notice to treat separately of the unchambered and chambered barrows; that arrangement having been followed in the memoir in the "Archæologia." The following is Dr. Thurnam's account of the external form of the simple or unchambered barrows:- "The long barrows are for the most part

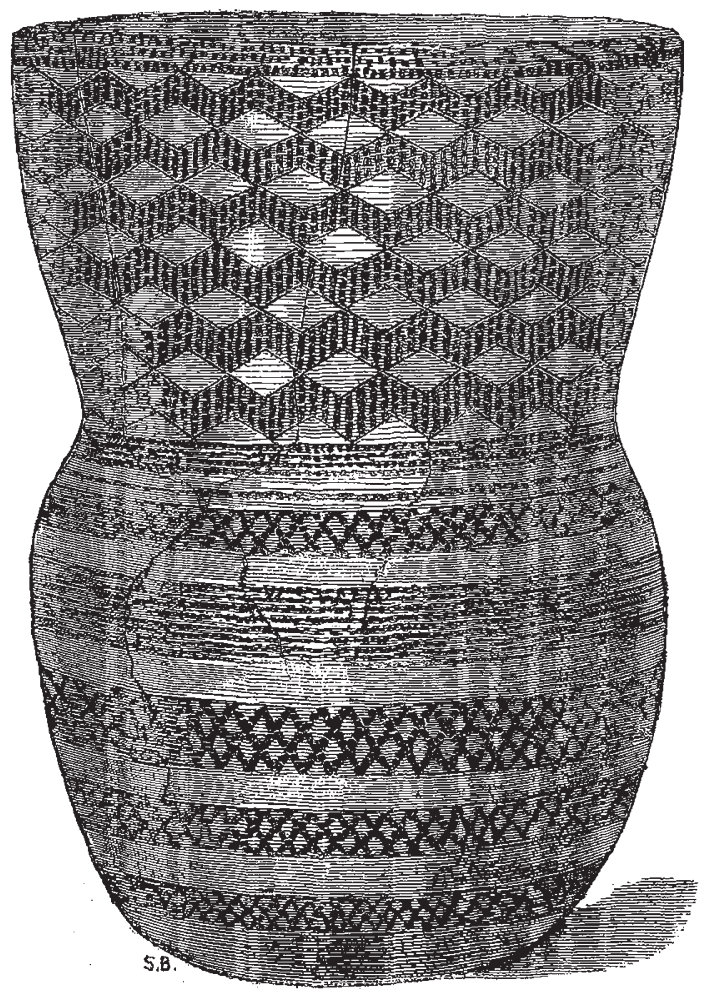

Fig. 3.-Drinking Cup with Secondary Interment. Figheldean, Long Barrow (scale $\frac{1}{2}$ linear)

fancy of the builders. He recognises three primary forms of round barrow-the bowl-shaped, the bell-shaped, and the disc-shaped; each of these three having again its three modifications. The long barrows are of two kinds -the simple barrows of South Wilts and Dorset, consisting merely of earth, chalk, and flints ; and the barrows of North Wiltshire, Gloucestershire, and Somersetshire, containing chambers or cists built of large stones.

Wiltshire is, par excellence, the county of long barrows, one district consisting of about 150 square miles, containing, on an average, one of these huge mounds in every six miles. The distribution of these monuments is a point of great interest. Unlike the round barrows, which usually occur in clusters, they are almost without exception solitary-generally two or three miles apart-and situated in some prominent position, usually the highest points of the hills, commanding extensive views over the downs. immense mounds, varying in size from one or two hundred to three and even nearly four hundred feet in length, from thirty to fifty feet in breadth or upwards, and from three to ten or even twelve feet in elevation. (See Fig. 1.) Along each side of the whole length of the tumulus is a somewhat deep and wide trench or ditch, from which trenches no doubt a great part, or sometimes even the whole, of the material of the mound was dug, but which it is very remarkable are not continued round the ends of the barrow. .... In by far the greater proportion of long barrows the mound is placed east and west, or nearly so, with the east end somewhat higher and broader than the other. Under this more prominent and elevated extremity the sepulchral deposit is usually found at or near the natural level of the ground." The great infre: quency of manufactured objects in these barrows and their rude character is very remarkable. Some "delicate 
and beautifully-chipped leaf-shaped arrow-heads" have been found in one or two instances, and this type of arrow-head, which is unbarbed, is the only one yet discovered. In no case has any trace of metal been found with the primary interments. Fragments of a coarse black pottery are occasionally met with, and in one barrow, that of Norton Bavant, Dr. Thurnam was fortunate enough to discover a tolerably perfect vessel of extremely rude construction, and utterly devoid of the ormamentation usually found in the pottery from the round barrows. Thanks to the courtesy of the Society of Antiquaries, we are enabled to reproduce Dr. Thurnam's drawing of this vessel. We are likewise indebted to the same Society for the other figures which illustrate this paper.

Remains of oxen of the ancient small species, Bos longifrons or Bos brachyceros, are often found in long barrows not far from the human remains; antlers and bones of the red deer are still more frequent. Tusks and bones of swine have also been discovered. It would appear that oxem were slaughtered at the funeral feasts, and that the heads and feet (the bones of which parts are more frequently found), not being used for food, were buried in the barrow, perhaps as offerings to the gods or to the spirits of the dead.

Secondary interments in the upper portion of long barrows are not infrequent, and afford valuable evidence of the antiquity of these tumuli. Some of these interments are assigned without hesitation to the Anglo-Saxon period; others, again, undoubtedly belong to the Ancient Britons of the bronze age, being sometimes burials after cremation, sometimes interments of entire skeletons in the contracted posture characteristic of the round barrows. In the latter case the remains are frequently associated with pottery undoubtedly of the round-barrow period. In order to show the difference between this pottery found with secondary interments in long barrows, and part of the long-barrow period itself, we reproduce (Fig. 3) an elegantly ornamented drinking-cup found at Figheldean, and now in possession of Dr. Thurnam.

In the present article we have only touched upon some of the most interesting of Dr. Thurnam's researches. It still remains for us to notice the chambered long barrows, and the most important evidence of all, that derived from the skeletons disinterred in both chambered and unchambered barrows. We have been able from the archæological evidence to gain some idea of the state of barbarism in which these primitive people lived; but still further information is to be obtained even on this point from the very bones of the people themselves; and from these sad relics alone can we obtain any ray of light as to the relation of these most ancient Britons to the population of more civilised times.

\section{HOW LARGE SEEMS THE MOON?}

IN a communication addressed to the Association 1 Scientifique, $M$. Viguier remarks on the linear dimensions which ordinary observers employ to define the size of celestial objects. They seem to imagine that they are really pointing out the size of a meteor, for instance, when they state that it was a yard in diameter, or the like. Of course, such a statement is absolutely without meaning to the astronomer; while the seemingly less precise mode of speaking which compares the size of a meteor to that of the moon, is in reality much more valuable. It is true that when an observer says a meteor was as large as the moon, he makes a wider error than when he says it was a yard in diameter; but the astronomer knows what one statement means, whereas he can form no real estimate even of the meteor's apparent size from the other.

If every observer formed the same estimate of the linear dimensions of a celestial object, one might indeed interpret a statement of the linear dimensions of a meteor. But this is not the case. As M. Viguier justly remarks, the short-sighted or the far-sighted person each forms his own estimate of the moon's real size, the position of the moon affects the judgment, nay, even the state of the weather influences our instinctive estimate.

But it is interesting to consider what is really implied by such a statement as that the moon is a foot in diameter. This is a size often assigned to the moon, I may remark, though many judge her to look larger. The moon subtends an angle of about half a degree, so that this estimate makes half a degree of the celestial sphere one foot in length. Thus the circumference becomes about 720 feet, and the radius about I 5 feet. This, at any rate, is the distance which the estimate assigns to the moon. And this last view is the more correct, since the varying estimates made of the moon's dimensions according to her position, suffice to show that the mind instinctively assigns to the celestial vault a somewhat flattened figure, the part overhead seeming nearest to us. In fact, a common opinion that the moon's diameter looks about twice as large when she is on the horizon as when she is nearly overhead, would assign to the celestial dome the figure of a segment of a sphere, less than a fifth of the sphere's surface being above the horizon.

It is worth noticing, though M. Viguier does not consider the point, that we can conclude from the estimated size of the moon as compared with the intervals separating certain stars, that the mind intuitively assigns to the moon a distance considerably greater than that of the fixed stars. For example, I find that if, when the moon is below the horizon, an observer be asked whether the distance separating the three stars in Orion's belt ( $\zeta$ from $\epsilon$, or $\epsilon$ from $\delta$, I mean) be greater or less than the moon's diameter, the answer is that it is about equal to that dimension. In reality, the moon's apparent diameter is but about one-third of the distance between these stars. It follows that the mind estimates the distance between the stars on a scale one-third only even of the small scale according to which it measures the moon; in other words, that it regards the distance of the fixed stars as about one-third that of the moon.

It may be, however, that the result of this comparison merely indicates that the mind assigns to the celestial sphere as seen on a moonless night a distance equal to only one-third of that which separates us from the faintly seen stars of a night on which the moon is full.

\section{RICHD. A. PROCTOR}

\section{NOTES}

WE are informed that her Majesty's Government has determined to issue a Royal Commission to inquire into the present state of Science in England. This step will be hailed with the liveliest satisfaction on all sides, and much good will certainly follow from such an inquiry, especially at a time when the arrangements for the prosecation of Science in this country are acknowledged on all hands not only to be "chaotic," but positively detrimental to the national interest. We learn that some of the commissioners have already been designated, but as their number is not yet complete, we withhold the names.

We have been favoured with a copy of the report just issued by the Rivers Pollution Commissioners on the Mersey and Ribble basins. We hope to retuin to this subject shortly.

ThE first Royal Society's Soirée of this Session will talie place on Saturday evening next.

Mr. E. RAy LANKester has been elected by examination to the Radcliffe Travelling Fellowship at Oxford.

WE have received the third part of Vol. I. of the Transactions of the Edinburgh Geological Society, containing the communi* cations made to that body during its session 1868-1869. These are numerous, and testify to the activity of the members of the 